\title{
LA DISPUTA POR LOS BIENES ECLESIÁSTICOS EN SEDE VACANTE EN EL ARZOBISPADO DE SEVILLA (1482-1624)
}

\author{
POR \\ José Antonio PInEdA-Alfonso ${ }^{1}$ \\ Universidad de Sevilla
}

RESUMEN

Este trabajo analiza los conflictos por el reparto de los bienes eclesiásticos en sede vacante en el arzobispado de Sevilla durante el período que va de 1482 a 1624 . Aunque numerosos estudios sobre esta cuestión nos ofrecen una imagen de la configuración de intereses en juego, nuestro trabajo pone la lupa en el caso concreto del arzobispado de Sevilla. Se muestran tanto los agentes implicados en el litigio como los mecanismos y procedimientos de gestión del conflicto de jurisdicción.

PALABRAS CLAVE: sede vacante; bienes eclesiásticos; conflicto de jurisdicción; arzobispado de Sevilla; Edad Moderna.

\section{ECCLESIASTICAL GOODS DISPUTE IN VACANT SEAT ON THE ARCHBISHOPRIC OF SEVILLE (1482-1624)}

\begin{abstract}
This paper analyzes the conflicts over the division of church property in vacant seat in the Archbishopric of Seville during the period from 1482 to 1624 . Although there are numerous studies on this issue which show us an image of the configuration of interests at stake, our work puts the magnifying glass in the case of the Archbishopric of Seville and shows the various factors involved in the litigation, as well as the mechanisms and management procedures of jurisdiction conflict.
\end{abstract}

KEY WORDS: vacant seat; ecclesiastical goods; jurisdiction conflict; Archbishopric of Seville; Modern Age.

Cómo CITAR ESTE ARTículo / CitATION: Pineda-Alfonso, J. A. 2019. «La disputa por los bienes eclesiásticos en sede vacante en el arzobispado de Sevilla (1482-1624)». Hispania Sacra 71, 143: 141-154. https://doi.org/10.3989/hs.2019.010

Recibido/Received 14-09-2016

Aceptado/Accepted 17-01-2017

\section{INTRODUCCIÓN}

Tenemos algunas evidencias de la disputa por los expolios y las rentas eclesiásticas en sede vacante en la España medieval. ${ }^{2}$ La más antigua parece ser el caso de San Isidoro, aunque aquí solo aparecen dos bandos en liza, la familia

1 apineda@us.es/ORCID iD: https://orcid.org/0000-0002-6379-5686

2 Calvo Cruz 2005. El expolio comprendía el patrimonio, bienes muebles y objetos valiosos de los obispos fallecidos mientras que las rentas de sede vacante las formaban todos los bienes y rentas que se producían entre el fallecimiento y la nueva provisión. del difunto y la Iglesia. ${ }^{3}$ Algunos tratadistas han mantenido que las necesidades del erario pontificio durante el Cisma de Aviñón (1378-1417) dieron lugar a un aumento de las exacciones y del control de las rentas de los expolios y sedes vacantes. ${ }^{4}$ En algunos países esto nunca se admitió, caso de Alemania; en otros se recibieron en principio y después fueron rechazadas, como en Francia, y en España los expolios

3 Castillo Maldonado 2012

4 Golmayo 1896, Tomo II. Capítulo XXVI. Del peculio de los clérigos y de los derechos en los frutos de sus beneficios. 309.-Reservas de los espolios y vacantes a favor del erario pontificio. 
sólo tuvieron lugar en los obispados y arzobispados, porque los clérigos, según las leyes recopiladas, tenían derecho de testar los bienes profecticios. Así lo vemos en 1482 cuando la Santa Sede decretó una bula para que ningún clérigo pudiese testar sin licencia apostólica. Esta decisión fue apelada por el cabildo sede vacante de Sevilla, pues según los canónigos iba en contra de la «antiquísima costumbre de los Reinos de España». ${ }^{5}$

Para la recaudación de estas rentas, y de otras, los pontífices enviaron colectores que debían atenerse a los convenios particulares que se hubiesen acordado con cada Iglesia o cabildo. ${ }^{6}$ El sistema de colecturías se consolidó en Castilla con la expansión de la fiscalidad pontificia durante los siglos XIII y XIV. Los oficiales aviñoneses eran nombrados por la autoridad pontificia y solían llevar aparejada la condición de nuncio, disponiendo de la capacidad de imponer censuras especiales que no podían ser levantadas por el clero local, sólo se podía apelar de ellas a la Sede Romana. ${ }^{7}$ En el siglo XIV se habían convertido ya en funcionarios fijos con una demarcación territorial variable bajo su jurisdicción, pero este reparto se fue consolidando en dos grandes zonas, una al norte del Sistema Central y otra al sur. ${ }^{8}$

Con el establecimiento de un único nuncio colector general se simplificó el complejo entramado fiscal y además su residencia permanente en la corte permitió unas relaciones más fluidas con la Corona, atenuando la desconfianza hacia los oficiales enviados por Roma..$^{9} \mathrm{El}$ nuncio nombraba a uno o dos subcolectores generales y éstos a su vez dispusieron de subcolectores diocesanos conocedores del ambiente local en el que se iba a producir un más que probable conflicto por el cobro de las rentas. Su posición nunca fue cómoda pues encontraron resistencias por parte de sus propios colegas de cabildo, que alegaban el uso inmemorial de cobrar y administrar estas rentas, y a veces por parte de la autoridad regia, que intentaba evitar la salida de oro de Castilla.

Durante la Edad Media, la Corona intentó apropiarse de algunas de las rentas eclesiásticas. ${ }^{10} \mathrm{El}$ caso de los obispos

5 (A)rchivo de la (C)atedral de (S)evilla. Sección I. Secretaría. Autos Capitulares de Cabildo Pleno. Libro 3, fol. 115. 19-6-1482.

6 Fernández Alonso 1957; Novísima Recopilación... 1805-1829, Libro II, Tit. XIII, Ley 1‥

Sobre la labor de los nuncios y legados pontificios en Castilla y sobre sus relaciones con la Cámara Apostólica durante la Edad Media véase Villaroel González 2013. Algunas de las obras clásicas en esta materia son los trabajos de Zunzunegui 1953, 1960, 1961, 1964. Sobre la labor económica y fiscal de distintos nuncios y legados pontificios en diferentes épocas véanse Serrano y Pineda 1915; Mendi 1964; Fernández Alonso 1954, 1957, 1963; Trenchs Ódena 1970-1971, 1978; Díaz Martín 1981.

8 Fernández Conde y Oliver 1982a: 400.

9 Fernández de Córdova Miralles 2005: 656 y ss.

10 Otra aportación en este campo es la de Rey Castelao 1987. Las disposiciones reales para proteger los bienes eclesiásticos durante la sede vacante son numerosas e indicativas del deseo de apropiarse de ellas, véase por ejemplo: Ruiz Asencio, J. M. Colección documental de la Catedral de León, núm. 1989. Archivo del Centro de Ciencias Humanas y Sociales. Junta para Ampliación de Estudios. Centro de Estudios Históricos. Instituto de Estudios Medievales. Archivo Fotográfico Claudio Sánchez Albornoz. Diplomata et chartae. Archivo de la Catedral de León. AEH Caja 20, Carp. 2, doc. 1. Fernando III concede a la iglesia de León y al obispo don Rodrigo que ni él ni sus sucesores puedan tomar bienes del obispo, de la iglesia o de sus hombres cuando la sede esté vacante. León, 6-12-1231; Ídem, núm. de Pamplona del siglo XIV es representativo de cómo los reyes y el papado se disputaron los derechos fiscales de los reinos. ${ }^{11}$ Aunque la actitud real pasó de la colaboración a la resistencia, dependiendo de las coyunturas internacionales y de las complejas relaciones políticas con la Santa Sede. ${ }^{12}$ Durante el siglo XIV, la usurpación y malversación de estos bienes, incluso por parte de los reyes, fue un hecho frecuente,$^{13}$ así como la extralimitación de los funcionarios aviñoneses que utilizaron con rigor las sanciones canónicas y tuvieron que hacer frente a veces a agresiones graves, pillajes y robos. ${ }^{14}$ Para evitar la usurpación o malversación de estos bienes, en las Partidas encontramos cómo los cabildos eclesiásticos encomendaban a los reyes el derecho de guardanía, para que los protegiesen hasta su entrega al sucesor del obispo o arzobispo. ${ }^{15}$ Sin embargo, este derecho cesó con el nombramiento de colectores apostólicos de la Santa Sede. Las cortes y la Corona alegaron que esto iba «en perjuicio de los pobres» y reclamaron el restablecimiento del antiguo orden. ${ }^{16}$

Conocemos la oposición de los Reyes Católicos al envío de agentes pontificios, hasta el punto de solicitar al Papa, en la Asamblea de Sevilla de 1478, que no enviase colectores y que nombrase algún lego que tuviese el cargo de cobrar las rentas. ${ }^{17}$ Uno de estos legados fue Bernardino López de Carvajal, que vino a España como nuncio en 1485 para

2149. Archivo de la Catedral de León, AEH Caja 20, Carp. 3, doc. 4. Alfonso $X$ confirma el privilegio de su padre, Fernando III, a la iglesia de León para que el rey no pueda tomar bienes ni hombres de la iglesia leonesa cuando la sede esté vacante. Sahagún, 6-04-1255; Lera Maíllo, J. C. Catálogo documental, doc. 629 (regesto). Ídem, Archivo de la Catedral de Zamora. AEH Caja 64, Carp. 3, doc. 23. Alfonso X junto con su mujer Violante y sus hijas Berenguela y Beatriz toman bajo su protección a la iglesia catedral de Zamora y al cabildo, estableciendo que los bienes episcopales en caso de la sede vacante nadie los pueda tomar y queden en poder del cabildo. Valladolid, 15-10-1255; Garrido Garrido, J. M. Documentación de la Catedral de Burgos, III, doc. 151. Ídem, Archivo de la Catedral de Burgos. AEH Caja 5, Carp. 1, doc. 25. La Infanta doña Berenguela confirma a petición del Cabildo de Burgos un privilegio de Alfonso VIII (1181) en el que concedía exención de tributos y protección de bienes durante la sede vacante. Monasterio de Santa María la Real, 20-07-1278; Álvarez Álvarez, C. Colección documental de la Catedral de León, núm. 3150. Ídem, Archivo de la Catedral de León. AEH Caja 21, Carp. 1, doc. 2. El procurador del cabildo de la iglesia de León presenta ante don Juan Domínguez de Valmadrigal, compañero de ella, vicario general de este obispado por autoridad del cabildo, sede vacante, y ante Gonzalo Fernández de Llanos, juez por el rey en la ciudad, la carta del rey Fernando IV (1295) por la que a petición de los obispos, cabildo y clerecía de sus reinos, les otorgaba que no embargarían los bienes de los prelados cuando éstos mueran, sino que quedarán a disposición de los cabildos para cumplir sus deudas y testamentos, que no se echarán pechos a los clérigos y que, cuando un clérigo fuera preso por la justicia, será entregado a su prelado. León, 25-02-1345.

11 Goñi Gaztambide 1958: 157, 1959, 1960, 1962, 1979.

12 Villaroel González 2013; Pérez Prendes 1986.

13 Fernández Conde y Oliver 1982b: 386, 1982a: 398.

14 Ibídem: 399.

15 Otro ejemplo de la intervención por parte de los reyes de las rentas en sede vacante es el caso de Lope de Rivas, obispo de Cartagena (1480). Véanse también Ortuño Molina 2002: 56 y ss.; Aguadé Nieto 1982: 30 y ss.; Barrio Gozalo 1987, 1990: 57, 2004: 252-386, 2010a: 313, 2010b; Pujol Aguado 1995. También conviene ver Domínguez Ortiz 1974; Hermann 1988: 149-189.

16 Estas reclamaciones se contenían en el famoso Memorial de Chumacero y Pimentel a Urbano VIII en nombre de Felipe IV en sus artículos 8 y 9 donde se pedía la reforma de los expolios y vacantes.

17 Fernández de Córdova Miralles 2005: 656. 
gestionar algunos asuntos, entre ellos arreglar los conflictos originados por los expolios de las diócesis vacantes de Coria, Oviedo, Córdoba, Badajoz y Ciudad Rodrigo, y cobrar algunas rentas que se debían. ${ }^{18}$ En 1486 la embajada del conde de Tendilla consiguió en Roma la cesión de todos los expolios de Castilla, pero los conflictos con la Corona se agudizaron en el último decenio del siglo XV. ${ }^{19}$

Durante el pontificado de Alejandro VI (1492-1503), los expolios fueron motivo de discordia permanente con la Santa Sede. El caso del cardenal González de Mendoza, que dejó a la reina como testamentaria, es un ejemplo. Y aunque la soberana se resistió a entregar el expolio, finalmente accedió a conceder la tercera parte de todos los bienes dejados por el arzobispo. ${ }^{20}$ En 1497 se planteó de nuevo la disputa y los reyes protestaron porque no se respetaba el acuerdo al que se había llegado con Carvajal en 1484. ${ }^{21}$ Finalmente, en 1498 el cardenal Cisneros tuvo que pagar más de 8 millones y medio de maravedíes a la cámara apostólica por el expolio del cardenal Mendoza. ${ }^{22}$

Para hacernos una idea de las riquezas que suponían estos expolios y rentas, y de las apetencias que provocaban, sirvan algunos ejemplos de casos notables. Como el de Francisco de Sandoval, oidor de la audiencia de grados de Sevilla, que estando obligado a poner 400 ducados del expolio del cardenal don Fernando Niño de Guevara en poder del depósito general no lo hizo y se los entregó a Gerónimo González de Villanueva, con el que tenía tratos. Cuando éste murió, sin haber dado instrucciones ni órdenes sobre este depósito, acudió a su casa y sacó de ella «muchos talegos de monedas y dejó encerrados papeles y joyas y se llevó las llaves». ${ }^{23} \mathrm{O}$ el del expolio del arzobispo de Burgos en 1656, que supuso la llegada a Madrid de 31 arrobas de oro y 46 de plata, sortijas, pectorales, un talego de perlas, estribos de oro, siete cargas de reales, 50 libras de ámbar gris y joyas de diamantes. El rey terminó concertándose por 50.000 ducados con la cámara apostólica y el envío de un pectoral y tres sortijas de diamantes al Papa, uno de los cuales «se dice es el mejor que ha entrado en España». ${ }^{24}$

LAS RENTAS EN LA SEDE VACANTE DE LOS CARDENALES DON Pedro González de Mendoza (1482) y don Diego HuRtado DE MENDOZA (1503)

Esta problemática podemos observarla en el arzobispado de Sevilla en el período que hemos estudiado (1485-1624), cuando se planteaba, en sede vacante, el reparto de las rentas del arzobispado y de la herencia del prelado muerto. Un primer caso lo tenemos en 1485 , en el pleito por el reparto de las rentas de la mesa de don Pedro González de Mendoza, que fue arzobispo de Sevilla de 1474 a 1482 y de aquí pasó a Toledo. A éste le siguió don Iñigo Manrique de

\footnotetext{
18 Ibídem: 80-82.

19 Ibídem: 50

20 Ibídem: 656.

21 Ibídem: 556-558.

22 Ibídem: 80-82.

23 (A)rchivo (M)unicipal de (S)evilla. Sección XIII. Archivos Importantes, siglo XVII, Tomo 5, Oidor: una carta donde se denuncia que Francisco de Sandoval.

24 Barrionuevo 1968. Avisos 1654-1658: 296-301. Madrid 5 de febrero de 1656, CXXXI.
}

Lara, que lo fue de 1483 a 1485, y fue sustituido por don Diego Hurtado de Mendoza que ocupó la silla de 1486 a 1503. Pero en el pontificado de don Iñigo Manrique de Lara todavía se dirimían las cuentas de la sede vacante de don Pedro González de Mendoza.

En 1485 fue nombrado colector apostólico para el cobro de las rentas de la mesa don Pedro de Frías, juez y vicario general en la audiencia de Alcalá de Henares por don Pedro González de Mendoza, cardenal de España y arzobispo de Toledo. Éste, a su vez, delegó en Diego Sánchez, procurador del arzobispo don Diego Hurtado de Mendoza, que se presentó con sus poderes el 23 de diciembre en el cabildo de canónigos, que a la sazón eran los depositarios de la jurisdicción ordinaria del prelado en sede vacante..$^{25}$

El documento venía refrendado y autorizado por el notario apostólico y secretario del arzobispo, y en virtud del mismo requería al cabildo en sede vacante para que mandase responder al cardenal en su reclamación de los frutos que se debían de la mesa arzobispal, desde el día que fue proveída la Iglesia de Sevilla, tras su salida y pase a Toledo, tal como se contenía en la bula de la Sede Apostólica. Los canónigos dijeron que obedecían el mandamiento apostólico, sin embargo dieron orden al receptor de las rentas nombrado por el cardenal para que no se entrometiese ni recibiese nada en el cobro de las rentas ni en la parte del arzobispo.

Pero el conflicto no se entablaba solo entre el colector de la Santa Sede y el cabildo sino que los reyes, por carta de 10 de enero de 1485, habían comunicado al mayordomo mayor de la mesa arzobispal, el jurado Antón Serrano, que habían nombrado a Alfonso de Toledo, vecino de Córdoba, para que recibiese: "las rentas, pechos, e derechos e diezmos e primicias que pertenecen a la Mesa Arzobispal de la Iglesia de Sevilla asi en Sevilla como en otros lugares deste arzobispado a nuestra suplicación». ${ }^{26}$

Días más tarde, Alfonso de Toledo informaba a los reyes que los concejos y corregidores y otras personas del arzobispado que debían pagar las rentas eclesiásticas no se las entregaban, desobedeciendo el mandato real. Ante esto, los reyes mandaron a todos los corregidores, asistentes, concejos, alcaldes, alguaciles, caballeros veinticuatros, jurados y "omes buenos» del arzobispado que diesen todo el favor y ayuda que les pidiese su receptor de las rentas para que:

... fagais y ejecutéis en los tales consejos e arrendadores e fieles e cogedores meros e otras personas que deben pagar. $\mathrm{E}$ los bienes que así fizieredes las dichas execuciones los vendais e remateis en almoneda publica... e entreguéis al dicho Alfonso de Toledo los maravedíes. $^{27}$

Los distintos oficiales de la jurisdicción real se veían así en la encrucijada de tener que obedecer los mandatos regios, exponiéndose de esta manera a ser excomulgados por la autoridad apostólica que se resistía a que los reyes interviniesen en el cobro de las rentas eclesiásticas.

25 Seguimos los autos capitulares en sede vacante de don Pedro González de Mendoza contenidos en: (A)rchivo de la (C)atedral de (S) evilla. Sección Secretaría. Autos Capitulares de Cabildo Pleno. Libro 3, año 1485 , fol. 24 y ss.

26 Carande y Carriazo 1968: Tomo III, años 1479-1485, doc. II-402.

27 A.C.S. Sección I. Secretaría. Autos Capitulares de Cabildo Pleno. Libro 3, fol. 24 y ss. año 1485. 
En la sede vacante del cardenal Hurtado de Mendoza (1503), de nuevo se planteó la disputa por el reparto de las rentas de la mesa arzobispal. Esta vez el nuncio nombró como subcolector al maestrescuela Jerónimo Pinelo, canónigo de la catedral, que en calidad de tal debía reclamar la parte de las rentas de la sede vacante a prorrata que correspondía a la cámara apostólica romana. ${ }^{28}$ Por otra parte, el sábado 21 de enero de 1503 se recibió una cédula de los reyes en la que reclamaban al colector del nuncio y al tesorero de la mesa arzobispal nombrado por él, Francisco Pinelo, la parte de las rentas del expolio que pertenecía al cardenal muerto y a sus herederos. El deán quiso ver la cédula, pero el maestrescuela respondió que no se la podía dar pues, aunque canónigo, su fidelidad al cabildo estaba condicionada por la que debía, como subcolector de las rentas del arzobispado en sede vacante, al nuncio colector general.

En efecto, este conflicto de lealtades va a ser una constante, así lo vemos cuando, acto seguido, el deán mandó al subcolector y a su tesorero que saliesen del cabildo porque se trataban asuntos relativos a las rentas en sede vacante. Además, este conflicto de lealtades tuvo otra respuesta contundente por parte de los canónigos reunidos en cabildo. Dando orden a su notario de los autos capitulares para que notificase a su receptor de los frutos y rentas del arzobispado, Marcos de Luzio, que no obedeciese al subcolector apostólico, y que desde "oy en adelante no acudiese al Maestrescuela con maravedíes de la renta», y que los pagos los hiciese con licencia del tesorero de la mesa nombrado por ellos.

Durante los meses de febrero y marzo se sucedieron los correos a Madrid con cartas del cabildo para los reyes sobre la cobranza de los frutos de la mesa. En la corte se encontraban las otras partes interesadas en el reparto de las rentas arzobispales en sede vacante. El nuncio colector general de los reinos de España, que defendía los intereses de la Santa Sede, y el monarca, que pretendía que las rentas provenientes de sus súbditos no terminasen en Roma. Mientras tanto, los canónigos daban órdenes a su receptor Marcos de Luzio para que librase distintas cantidades para hacer reparaciones en la fortaleza de Cantillana, que pertenecía a la dignidad, y para "arar de segundo yerro» los olivares de Umbrete, Lopas y Rianzuela. ${ }^{29}$

Hasta aquí el cabildo había hecho valer su jurisdicción resistiéndose a las pretensiones del subcolector. Pero el 27 de abril apareció el colector apostólico nombrado por la Santa Sede, el protonotario don Francisco Ortiz, arcediano de Briviesca y canónigo de Toledo, que presentó una provisión al cabildo en la que mandaba que cobrasen todo lo que hallasen de todos los frutos y rentas del arzobispo cardenal difunto y los pusiesen en depósito, junto con lo que después recibió la mesa arzobispal en sede vacante. El cabildo sede vacante lo contradijo, y dió poder al capellán de la capilla de los Reyes, Juan de Pinos, para que en sus nombres le intimasen una apelación como administradores de la mesa arzobispal, y para que apelase también ante el rey y la reina y ante los del Consejo Real.

El martes 27 de junio de 1503, el colector presentó dos breves del Papa Alejandro VI. Uno dirigido a los canónigos

28 Los autos capitulares de la sede vacante del Cardenal Hurtado de Mendoza se encuentran en: A.C.S. Sección Secretaría. Autos Capitulares de Cabildo Pleno. Libro 6, 13 de enero de 1503.

29 Ibídem, sábado 11 de marzo y jueves 27 de abril de 1503. y otro al maestrescuela Jerónimo Pinelo (subcolector apostólico) y a Francisco Pinelo (tesorero del subcolector), en los que mandaba cobrar los frutos y rentas de la mesa arzobispal sede vacante y pagar su salario a los receptores a razón de 24.000 maravedíes anuales, que era lo que el cardenal Hurtado de Mendoza pagaba de salario por el oficio de contador de la mesa. Con esto el colector pretendía liquidar y despedir a los receptores de las rentas que obedecían al cabildo, y nombrar a sus propios oficiales, que de esta manera debían seguir sus instrucciones en todo lo referente al cobro y depósito de las rentas.

El nombramiento de oficiales en sede vacante, sobre todo los contadores, receptores y el tesorero, se iba a convertir en uno de los elementos cruciales de la disputa, pues de ellos dependía el cobro y depósito de las rentas. Así, fue frecuente que tanto el cabildo sede vacante como el subcolector del nuncio nombrasen sus propios oficiales con el consiguiente conflicto.

Finalmente, en julio, el cabildo se avino a un acuerdo y mandó al chantre y al canónigo Fernando Alfaro que se reuniesen con el subcolector para que hiciesen la cuenta de los frutos y rentas de la mesa que habían cobrado los receptores desde el día de la muerte del cardenal. El martes 8 de agosto mandaron a los contadores de la mesa que averiguasen las cuentas que habían hecho los receptores (los canónigos Pedro de Yenens, Alonso de Ayora, Martín de la Campana y Lope Rodríguez) correspondiente a los frutos que recibieron de la mesa arzobispal en sede vacante, y lo que por mandato de los canónigos habían pagado, y les diesen su "carta de fin».

Los reyes solían reclamar en sede vacante que los alcaides de las fortalezas de los lugares pertenecientes al arzobispado les pagasen por la tenencia de las mismas. Así ocurrió el 19 de agosto de 1503, cuando el escribano real Juan de la Fuente presentó una cédula de la reina doña Isabel para que los alcaides de los feudos del arzobispo de Sevilla le pagasen las tenencias. En Cantillana la tenía mosén Diego Vadillo, al que mandaron pagar por el cargo el mismo salario que había establecido el cardenal Hurtado de Mendoza. En Almonaster sin embargo no había alcaide que tuviese la fortaleza.

Pero el cabildo de canónigos contestó a la reina que estaban en sede vacante y los frutos de la mesa arzobispal los recibía y cobraba el subcolector del nuncio, y que por un breve del Papa se les había mandado "con grandes censuras» que "desembargaran» y dejasen libertad al maestrescuela y a su padre, el genovés micer Francisco Pinelo, para que los cobrasen. Por tanto alegaban que no podían pagar las tenencias de los alcaides, pues los canónigos en sede vacante no tenían a su cargo la cobranza de los frutos, «así que sus altezas enviasen el recaudo a quien tuviese cargo de la cobranza para que los pagase». ${ }^{30}$

El 19 de septiembre mandaron al notario que hiciese la libranza de los salarios de todos los oficiales de la sede vacante, que fue refrendada por el subcolector apostólico, para que se pagase a cada uno de ellos las cuentas contenidas en las nóminas, pues los salarios de los oficiales del arzobispado se pagaban de la parte que le correspondía a la cámara apostólica. Hay que tener en cuenta que la

\footnotetext{
30 Ibídem, martes 19 de agosto de 1503.
} 
sede vacante era una oportunidad de adquisición de poder y rentas para los canónigos, pues asumían la jurisdicción ordinaria y la administración del arzobispado. Una de las primeras decisiones que tomaban los canónigos en sede vacante era el nombramiento de los oficiales del arzobispado, cargos que se repartían entre ellos. Entre estos estaban los tres jueces del consistorio, provisor, juez de la Iglesia y juez de testamentos, que tenían en nómina las rentas más altas por sus oficios.

Después trataron con los albaceas sobre el testamento y el reparto de la herencia del cardenal Hurtado de Mendoza y decidieron sobre asuntos menores relacionados con la contabilidad de las rentas, como el caso del alcalde de Cantillana, feudo del arzobispo, que había tomado ropas de los vecinos de la localidad y ahora el subcolector debía restituir los maravedíes correspondientes. En los meses siguientes observamos cómo los canónigos dieron órdenes para realizar distintas reparaciones y obras y librar su importe, a albañiles de las casas arzobispales, a operarios de los olivares de Umbrete, etc. Se trataba de realizar estos gastos antes de proceder al reparto de las rentas entre la cámara apostólica y los herederos del arzobispo.

El miércoles 20 de octubre de 1503 decidieron que lo que se pagaba por el molino a la fábrica de la iglesia de Olivares, de los fondos de la mesa arzobispal, lo pagase el subcolector de la parte de la cámara apostólica. Pues este molino, y el que se pagaba de la mesa capitular, era todo «para libros y ornamentos y otras cosas que era menester para el servicio de la Iglesia, pues el prelado y los canónigos en sede vacante estaban obligados a lo pagar ${ }^{31}$

El martes 5 de diciembre decidieron que los letrados del cabildo viesen los pleitos que había pendientes sobre el reparto de la hacienda del cardenal muerto, y lo que correspondía al Papa y al prelado de las rentas arzobispales. A tal fin "advocaron» todos los pleitos en los que habían proveído sentencia los jueces ordinarios, y admitieron las apelaciones hechas por los albaceas del cardenal, cometiendo las causas al provisor, el canónigo bachiller Lope de Madrigal, para que procediese en ellas. Y los que estaban pendientes de sentencia los advocaron también y se los dieron al juez de suplicaciones y testamentos, el doctor León. ${ }^{32}$ Con esto tomaban bajo su control todos los litigios que se habían generado en el proceso de reparto de las rentas.

Finalmente, el cabildo mandó a sus contadores que viesen la parte que pertenecía al pago de los frutos que rentó el arzobispado desde el día que murió don Diego Hurtado de Mendoza hasta que fue proveído don Juan de Zúñiga, y que se liquidase con la sede apostólica todo lo que se le debiese; pero al contador Martín de la Campana le ordenaron que no pagase la rata que correspondía al cardenal muerto, pues había pendiente un litigio con los herederos del cardenal por el reparto de la herencia.

En la sede vacante de don Juan de Zúñiga $(1504)^{33}$ y en la siguiente de don fray Diego de Deza $(1523)^{34}$ se repitieron los

31 Ibídem, 20 de octubre de 1503.

32 Ibídem, jueves 13 de diciembre de 1503.

33 A.C.S. Sección I. Secretaría. Autos Capitulares de Cabildo Pleno. Libro 5, Sede Vacante de don Juan de Zúñiga, fol. 68-80, año 1504.

34 A.C.S. Sección I. Secretaría. Autos Capitulares de Cabildo Pleno. Libro 5, Sede Vacante de don fray Diego de Deza, fol. 342, primero de agosto de 1523 . procedimientos vistos hasta aquí, el subcolector actuando en defensa de los intereses de la cámara apostólica y los canónigos en sede vacante ordenando a sus contadores y receptores que no les entregasen las rentas, y que librasen las cantidades correspondientes para las reparaciones acostumbradas y para el pago del salario de los oficiales de la nómina arzobispal. Pero sí observamos que en ninguna de las dos sedes vacantes aparece ningún representante de la Corona realizando gestiones para reclamar las rentas eclesiásticas, aunque las protestas de los monarcas continuaron. Así lo vemos en 1511 en los informes para la preparación del concilio de Letrán. Diego de Deza y el doctor Angulo, consejeros reales, se quejaron en ellos, entre otras cosas, del abuso que suponía la recaudación de los expolios episcopales. Pues provocaban la fuga de capitales, dificultaban la ejecución del testamento, impedían al prelado que llegaba hacer frente a los gastos de entrada y saldar las deudas dejadas, y eran además un agravio en comparación con lo que se hacía con otros países. ${ }^{35}$

En tiempos del emperador de nuevo intervino la Corona para que nadie pusiese manos en las rentas del obispado de Pamplona, que estaba vacante, sino que recayesen en una persona de confianza que desempeñase el cargo de administrador. ${ }^{36} \mathrm{Y}$ en 1522 se hicieron las Instrucciones para Adriano VI en las que se protestó por la simonía, las tasas fiscales de la cámara apostólica, las anatas y los expolios. ${ }^{37} \mathrm{Se}$ trataba de aprovechar las rentas de la Iglesia para mantener la política internacional. De aquí que los consejeros reales elevaran una serie de "memoriales para arbitrar dinero", en los que dieron su parecer Vozmediano, Galíndez de Carvajal, Diego Hurtado de Mendoza, el condestable, el almirante, el licenciado Vargas y otros peritos. ${ }^{38}$

\section{EL REPARTO DE LAS RENTAS A LA MUERTE DEL ARZOBISPO ALONSO MANRIQUE (1538-1539)}

Otra de las medidas que tomaba el cabildo de canónigos, en la lucha por las rentas de la sede vacante frente a las reclamaciones del colector apostólico, era nombrar unos diputados de las honras por el cardenal muerto, a fin de asegurar las rentas necesarias para la ceremonia. Sobre todo las "obsequias» que se daba a los beneficiados de la catedral por su asistencia de luto a las honras fúnebres. Los diputados invitaban a todos los señores que estuviesen en la ciudad, "duques, condes y marqueses», así como al cabildo seglar, al santo oficio, y a todas las «señoras e dueñas desta ciudad" y les rogaban que estuviesen presentes a las honras. ${ }^{39}$

En la sede vacante de don Alonso Manrique (1538), los diputados nombrados fueron los canónigos Juan de Moguer y Baltasar del Río, que junto con los contadores embargaron las rentas necesarias para hacer las «onras del reverendo

\footnotetext{
35 Fernández de Córdova Miralles 2005: 653.

36 Azcona 1984

37 Azcona 1982: 189.

38 Azcona 1982: 196-198.
}

39 Seguimos el relato de los autos capitulares de la sede vacante del Cardenal Manrique que se contienen en: A.C.S. Sección Secretaría. Autos Capitulares de Cabildo Pleno. Libro 16. Sede vacante de don Alonso Manrique, (1538-1539), 28 de septiembre de 1538. 
cardenal muerto», y concretamente 1.000 ducados que era costumbre gastar en las «obsequias que solía hacer el prelado». Para lo cual dieron orden de que se embargase el pan de los diezmos que estaba en poder de los fieles de Écija y Jerez, y "otros cualquier maravedíes que se hallaren». Estas «obsequias» se repartían por los contadores entre los beneficiados que estuviesen presentes con luto a las honras del cardenal. Como no había dinero efectivo para las costas y gastos mandaron que se vendiese el pan necesario para alcanzar la cantidad indicada.

Otra de las fuentes de conflicto en la sede vacante, el nombramiento y dependencia de los oficiales de la mesa para el cobro de las rentas, también podemos observarla en este caso, pues el receptor nombrado por el subcolector del nuncio pretendió recibir frutos y rentas de la Mesa. El 5 de octubre de 1538 el cabildo cometió a los canónigos licenciado Sandoval, licenciado Santillán y doctor Ramírez para que tratasen este asunto con el subcolector e hiciesen las apelaciones que les parecieren. ${ }^{40}$ También escribieron sobre este asunto al nuncio, contradiciendo su intención, y cometiendo a los letrados del cabildo para que estudiasen el negocio. Las negociaciones y las idas y venidas de correos a Madrid continuaron, así vemos a los contadores librando veinte ducados de oro en los receptores para pagar el salario de los carteros y de los diputados enviados a la corte para negociar con el nuncio el reparto de las rentas. ${ }^{41}$ Sin embargo, tampoco aquí aparece la Corona como parte interesada en el conflicto.

Para hacer frente a este desafío a la jurisdicción ordinaria enviaron correos por todo el arzobispado y un edicto de embargo a todos los fieles del pan de Sevilla y su arzobispado para que no diesen a nadie el pan de la mesa arzobispal, bajo pena de excomunión. $Y$ el viernes 8 de noviembre los canónigos mandaron a Alonso Ordiales, notario repartidor de los frutos y rentas, que no se sacase ningún repartimiento de pan ni maravedíes de la mesa arzobispal del año 1538 hasta que el cabildo lo mandase, y que los contadores y receptores de las rentas no consintieran que ninguna persona cobrase pan ni maravedíes ni otras cosas, ni del año anterior ni de la sede vacante, sin que primero tuviese el poder del cabildo. Y que los maravedíes, pan, trigo y cebada del año 1538 que se hallaren en poder de los fieles, como arrendadores de los diezmos que tocaban a la mesa arzobispal, no se entregasen al subcolector hasta que se hiciera la renta y se pagaran las deudas del tiempo del cardenal Manrique, las reparaciones de las iglesias y fortalezas, los salarios de los oficiales y capellanes, y otras costas, cargos y gastos a los que estaba obligada la mesa arzobispal. Advirtiendo a los fieles arrendadores que si lo pagasen al subcolector sin orden del cabildo responderían con sus bienes y haciendas.

Sin embargo, el subcolector del nuncio ya había procedido a nombrar a sus propios oficiales para el cobro de las rentas, armados con un requerimiento para embargar el trigo. Uno de estos era Diego Arias, vecino de Sevilla, que había sido nombrado por el subcolector receptor de la mesa arzobispal para el cobro de los frutos y rentas. El cabildo respondió ordenándole que no se entrometiese a cobrar ni re- cibir pan ni maravedíes bajo pena de excomunión, y al fiel de Utrera, Rodrigo Velagran, y posteriormente a los demás fieles del pan de los lugares, que de los diezmos pontificales que tenían depositados vendiesen todo el pan que le indicase el contador Diego Vázquez Aldrete y entregasen todo el dinero efectivo que hicieran al receptor de la mesa arzobispal. ${ }^{42}$

El 14 de noviembre dieron orden a los contadores de la mesa arzobispal para que vendiesen cien fanegas de trigo que tenía Juan Díaz Aragonés, fiel del pan de la collación de Santa María de Sevilla, de las rentas de las monjas y frailes que tocaban a la mesa, a pesar de cualquier embargo o requerimientos que les hubiesen hecho. $Y$ de las rentas de las monjas y frailes en la iglesia de Lebrija que vendiesen cien fanegas de pan, y si no las hubiese en Lebrija que las tomasen de Utrera, y las entregasen a los receptores de la mesa nombrados por el cabildo.

El jueves 28 de noviembre cometieron al arcediano de Sevilla, al chantre Juan de Moguer, a Rodrigo de Solís y al doctor Ramírez, con los contadores de la mesa, para que se entendiesen con el subcolector y con los herederos y albaceas del cardenal. Al contador Alonso Ordiales le mandaron que hiciera la "prorrata» de lo que pertenecía a la cámara apostólica y a la mesa arzobispal. A la parte de la cámara correspondía el pago de los salarios de los oficiales sede vacante, y a la de la mesa, el pago de las reparaciones que fuesen necesarias en las casas y fortalezas. A continuación alzaron el embargo de la parte de la mesa y mandaron a los fieles del pan de Sevilla y su arzobispado, tanto eclesiásticos como seglares, que diesen su parte a Juan Antonio Picolomini, heredero del cardenal Alonso Manrique, al que pertenecía la parte de la mesa, una vez descontados los gastos de reparaciones. Pero no alzaron el embargo de la prorrata que pertenecía a la cámara apostólica.

Al día siguiente, los legados del cabildo fueron con el letrado de la sede vacante a ver la copia del breve que presentó el colector del Papa. Previamente se les había advertido que "estuviesen prevenidos» para responder, advirtiendo "que ninguna iglesia deste reino tiene la administración como la tiene esta santa iglesia de Sevilla». ${ }^{43}$ Pues el nuncio les había intimado una monitoria y tenían que responder si obedecerían a sus pretensiones de nombrar sus propios receptores de las rentas. El cabildo catedral sevillano pretendía que tenía mayores prerrogativas que el resto de las iglesias de España en sede vacante, pues además del gobierno y administración del arzobispado, había nombrado desde tiempo inmemorial a los oficiales mayores y menores del gobierno arzobispal.

Este era otro aspecto del conflicto pues el colector pretendía nombrar, no sólo a los oficiales de la mesa, sino también a los oficiales mayores y menores de las audiencias y del resto de órganos del gobierno arzobispal, y el cabildo defendía su derecho a nombrar a todos los oficiales en sede vacante, excepto los que se arrendaban, que pertenecían a la cámara apostólica. Así, el 7 de noviembre de 1538 se presentó en el cabildo Juan Zayas, que dijo ser secretario del señor Juan Poggio, nuncio de Su Santidad, y dijo que él

\footnotetext{
$40 \quad$ Ibídem, 5 de octubre de 1538.

41 Ibídem, 12 de noviembre de 1538.
} 
había sido nombrado notario de la audiencia del provisor y secretario y notario de los autos capitulares de la sede vacante por su señor el subcolector apostólico. Pero añadió que, como la presentación y provisión de dicho oficio tocaba al cabildo sede vacante, «se desistía y desistió, y se apartaba y apartó» de dicha nominación y provisión, renunciando cualquier derecho y dejando los oficios a los señores del cabildo para que lo proveyesen en la persona o personas que quisieren «e vien tuvieren como cosa cuya provisión toca a los dichos señores». ${ }^{44}$

Después de esto, atentos a la «avilidad suficiencia e buena fama» de los señores Juan Zuárez, notario apostólico, y don Juan de Zayas, estantes en la ciudad de Sevilla, los nombraron por notarios de la audiencia del provisor de Sevilla y su arzobispado, "con todos los derechos e ovenciones que suelen tener y han tenido los notarios de la dicha audiencia». ${ }^{45}$ Está claro que hubo un acuerdo previo, los notarios se desistieron de sus cargos renegando de la jurisdicción del subcolector, y el cabildo sede vacante les premió nombrándolos de nuevo en sus oficios. De esta forma aseguraban su continuidad cambiando de señor, pues el colector desaparecería tras el cobro de sus rentas, mientras el cabildo continuaría ejerciendo influencia y poder en el gobierno arzobispal. Preferían la fidelidad a un señor menos poderoso pero más cercano. También hubo problemas con los ducados que pedía el subcolector al notario de la vicaría de El Puerto de Santa María, pues los notarios de las vicarías, como oficios que se arrendaban, pertenecía cobrarlos al subcolector.

Con respecto a las reparaciones de iglesias y fortalezas, éstas se realizaban de la parte de las rentas de la mesa que pertenecía a los herederos del cardenal, por esto había que realizarlas antes de que se produjera el reparto. A tal fin mandaron que se embargasen ciertas cantidades en los fieles de los diezmos de todo el pan y trigo que tocaba a la mesa para asegurar el pago de las reparaciones. El arzobispo fray Diego de Deza había entregado al canónigo Juan Herrera, antes de morir, la cantidad de 13.000 maravedíes para el arreglo de las fortalezas, casas y posesiones de la mesa arzobispal. Estas cantidades fueron tasadas en la sede vacante anterior y ahora se tomaban como referencia para el gasto de las reparaciones. Esta tasación se les encomendaba a los alarifes, que averiguaban y apreciaban con los alcaides y alcaldes mayores de las fortalezas las cantidades que eran necesarias. ${ }^{46}$

Una vez retenidas estas cantidades, el 19 de diciembre, por nuevo mandamiento hecho a los fieles del pan de Sevilla y su arzobispado, se les ordenaba, como arrendadores de las rentas, que diesen y entregasen a Juan Antonio Picolomini, sobrino y heredero del cardenal, y que fue su mayordomo mayor, todo el pan del año que le tocaba prorrata a la mesa arzobispal, según el cálculo hecho por el contador Alonso de Ordiales. Pero no alzaron el embargo que tenían hecho con la prorrata de la cámara apostólica.

Por último, bajo la presión de los breves del Papa y de la amenaza de excomunión, acordaron obedecer los mandamientos del nuncio Juan de Poggio y alzaron el secuestro y embargo que tenían hecho sobre los frutos del arzobispado de la «rata» que correspondía a la cámara apostólica, pero protestaron y apelaron la cédula, porque se perjudicaba la preeminencia de su Iglesia. Y afirmaron que obedecían por las censuras que les había puesto el nuncio en la monitoria. Después, mandaron que los receptores de la mesa pagasen la parte que correspondía a Juan Antonio Picolomini, heredero del cardenal, y también la que correspondía a la cámara apostólica. Pero decidieron seguir el pleito en grado de apelación, haciendo venir a los letrados del cabildo para ver la forma de obedecer el breve. ${ }^{47}$

Otro contencioso que se planteó en esta sede vacante fue sobre los salarios de los oficiales del arzobispado. El viernes último de febrero de 1539 cometieron al licenciado Sandoval para que, junto al letrado del cabildo, hiciese un requerimiento al arcediano de Écija, que había sido nombrado subcolector apostólico, y al nuncio, don Juan Poggio, para que pagasen los salarios a los oficiales de la sede vacante según lo que había señalado el cabildo. El cabildo, como administrador del gobierno arzobispal en sede vacante, ordenó a los receptores de los frutos y rentas de la mesa que, de la cantidad que correspondía a la cámara apostólica, descontasen los salarios y pagasen a los oficiales de la sede vacante, pero las cantidades parecieron excesivas al subcolector y al nuncio, que presionaron para que se moderasen.

El conflicto por los salarios de los oficios arzobispales, que se repartían entre los propios canónigos y eran a menudo ejercidos por coadjutores o sustitutos, se entiende porque las cantidades que proponían suponía un aumento considerable con respecto a las sedes vacantes anteriores, en algunos casos con subidas del $400 \%$ (provisor y juez de la Iglesia pasaron de 15.000 a 60.000 maravedíes) y en otros de hasta el 500 \% (alcaides de Zalamea, Brenes, Villaverde y Umbrete pasaron de 5.000 a 25.000 maravedíes, y el alcaide de las casas y palacio arzobispal de 3.000 a 15.000 maravedíes).

Los salarios de los oficiales se pagaban de la parte correspondiente a la cámara apostólica y el aumento de los salarios de los oficiales, como el cobro de las "obsequias» de las honras por el cardenal, no era más que otra forma de retener las rentas antes del reparto. Sin embargo, tras la negociación con el subcolector decidieron por auto capitular rebajar sus pretensiones, «platicando sobre los salarios de los oficiales... por ciertos respectos que a ello les movía avía e ovieron por bien en lo que toca a los salarios se guarde este auto y no el pasado ${ }^{48}$ : al provisor 40.000 maravedíes, al juez 40.000, al juez de testamentos 30.000, a los cuatro visitadores, a cada uno 22.000, al obispo auxiliar 30.000 , al visitador de monjas 22.500 , al alcaide y alcalde mayor de Cantillana 33.884, al de Almonaster 22.500, al de Zalamea 18.750, al de Umbrete 18.750, al de Villaverde 18.750, al de Brenes 18.750, al alcaide y guarda de la casa arzobispal 11.250, al alguacil mayor 22.500, al alcaide de las cárceles 10.000 , a los dos contadores 30.000 maravedíes y 100 fanegas de pan a repartir entre ellos, al alcaide de las dos torres 8.000 y al secretario de la sede vacante 20.000 .

Aun así, esto suponía un aumento desproporcionado con respecto a la sede vacante anterior, así que el nuncio

\footnotetext{
44 Ibídem, jueves 7 de noviembre de 1538.

45 Ibídem.

$46 \quad$ Ibídem, 29 de noviembre de 1538.
}

47 Ibídem, 29 de noviembre de 1538.

48 Ibídem, lunes último día de septiembre de 1538, Auto de los Salarios. 
siguió presionando y tras una negociación con el subcolector libraron las partidas de los salarios de los oficiales de la sede vacante siguientes: al provisor 10.000 maravedíes, al juez oficial 7.500, al juez de suplicaciones 5.000, a los visitadores del arzobispado 4.000 a cada uno, al obispo para los actos pontificales 12.500 , al visitador de monjas 5.000, al alcaide y alcalde mayor de Cantillana con su alguacil 17.500, al alcalde mayor de Almonaster 5.000, al de Zalamea 5.000, al de Umbrete 5.000, al de Villaverde 5.000, al de Brenes 5.000, al secretario de los autos capitulares 3.000, al alcaide de las casas arzobispales 1.500 , al alcalde de las dos torres 2.500 , al alguacil mayor 5.000 y al alcalde de la cárcel arzobispal 5.000 .

Finalmente, tras este forcejeo, y teniendo en cuenta el tiempo que habían ejercido sus oficios los oficiales sede vacante, que no había sido el año completo, el miércoles 11 de junio de 1539 terminaron recortando aún más los salarios hasta llegar a las cantidades siguientes: para el provisor 5.000 maravedíes, para el juez 3.750, para el juez de testamentos y obras pías 2.500, para el obispo 6.250, para el visitador de monjas 2.500, para el alcaide y alcalde mayor de Cantillana 8.700, para el de Almonaster 2.500, para el de Zalamea 2.500, para el de Umbrete 2.500, para el de Villaverde 2.500, para el de Brenes 2.500, para el alcaide de las dos torres 1.850 , para el alcaide de la cárcel 2.500 y finalmente para el secretario de los autos capitulares de la sede vacante 1.500 maravedíes. La nómina montaba en total 54.750 maravedíes y como se ve la distancia entre las pretensiones iniciales y el resultado final de la negociación con el colector apostólico fue notable. ${ }^{49}$

Así pues, a partir del reinado de Carlos V, la colectoría de España, como órgano central organizado en torno a los subcolectores generales, tesoreros, notarios apostólicos, letrados y subcolectores territoriales, acometió una serie de reformas tendentes a solucionar la indefinición jurídica existente para incrementar su poder y su capacidad de exacción sobre las rentas de los obispados. Se trataba de fijar los derechos económicos pontificios, mejorar su gestión, agilizar los acuerdos con la Corona y familiares del prelado difunto, así como de establecer los cauces financieros para trasladar las recaudaciones a Roma a través del sistema bancario. ${ }^{50}$

Buena parte de estas reformas, que racionalizaron el sistema de cobro de las rentas, se debieron sin duda al nuncio-colector Giovanni Poggio. Desde 1529 empezaron a darse cuentas con regularidad, y entre este año y 1547 el colector contabilizó en conceptos fiscales menores 157.982 maravedíes. $^{51}$ En este período, las rentas de las sedes vacantes en España observaron un notable incremento. Por ejemplo, solo el expolio de don Juan de Tavera en 1545 produjo unos ingresos de 16.000 ducados. ${ }^{52}$ Fue en esta época además cuando quedó consolidado el cargo de colector general, que ya había surgido en la transición del siglo XV al XVI, y sus privilegios. ${ }^{53}$ Sin embargo, la vinculación entre la nunciatura y la colectoría nunca fue admitida por la Corona, e incluso posteriormente, en los reinados de Felipe

\footnotetext{
49 Ibídem, miércoles 11 de junio de 1539.

50 Carretero Zamora 2013: 82-83.

51 Azcona 1982: 195-196.

52 Carretero Zamora 2013: 84

53 ídem.
}

II y Felipe III, el Consejo de Castilla pidió la limitación de los poderes del nuncio colector, y en concreto de su capacidad de fulminar censuras especiales que sólo podían apelarse en Roma.

\section{LAS RENTAS EN LA SEDE VACANTE EN LA SEGUNDA MITAD DEL SIGLO XVI}

De la sede vacante de García de Loaysa, año 1546, sólo tenemos noticias de cómo el escribano mayor del consistorio, Iñigo López, siguió a la muerte del arzobispo en su oficio y pagó los derechos de arrendamiento al subcolector de la cámara apostólica, el maestrescuela Sebastián Ponce. Además, el escribano no sólo se obligó a pagarle, sino que, como el subcolector estaba procediendo contra los deudores de la mesa arzobispal, y hacía diligencias contra ellos, se comprometió en el contrato a dar todos los despachos a la mesa y cámara sin cobrar derechos y sin pedir descuentos a cambio en el precio del arrendamiento. ${ }^{54}$

En la sede vacante de Gaspar de Zúñiga y Avellaneda (1571) de nuevo nos encontramos a los canónigos mandando a los alcaldes y justicias de Cantillana, Brenes y Villaverde que guardasen el pan y no consintiesen sacarlo y gastarlo sin la autorización de los canónigos sede vacante, pues eran rentas de feudos arzobispales que ahora pasaban a ser controladas directamente por el cabildo. ${ }^{55}$ Después mandaron a los notarios de las audiencias del provisor y del juez de la Iglesia, así como al teniente de la cárcel arzobispal, que acudiesen a la cámara apostólica con el «servicio» que pagaban al arzobispo y les dieron poder para ejercer sus cargos. En el caso del teniente de la cárcel se planteó un litigio ante el provisor, porque nunca antes había intervenido el subcolector en su nombramiento, ni había recibido el arrendamiento de este oficio. Este hecho confirma noticias anteriores y nos muestra cómo el arrendamiento de oficios era otra de las rentas en disputa en sede vacante.

Al subcolector del nuncio, don Hernando Saucedo, arcediano de Niebla, le permitieron estar presente en la elección de los oficios con la condición de que no se le proveyese ninguno tocante a la sede vacante. Éste mandó inventariar los bienes del arzobispo Gaspar de Zúñiga al albacea testamentario Alonso de Revenga, ${ }^{56}$ y cobrar lo que debían los arrendadores de los diezmos al contador y mayordomo mayor en nombre de la cámara apostólica.

En 1571 todavía se arrastraban las cuentas del expolio de don Fernando Valdés, muerto en 1568. El receptor y administrador de las rentas de la mesa por la cámara apostólica en la sede vacante del citado prelado había sido Simón de Valdés, pariente del arzobispo y hombre de su confianza que desempeñó distintos oficios durante su pontificado. Después ocupó el oficio de mayordomo de la mesa arzobispal con el arzobispo Gaspar de Zúñiga y a su muerte también fue el administrador de su expolio. Ahora aparecía recibiendo del administrador del almojarifazgo de la ciudad, el señor Pedro Luis Torregrosa, y en su nombre del genovés Vicencio Spínola, la renta de los juros que tenía

\footnotetext{
54 (A)rchivo de (P)rotocolos (N)otariales de (S)evilla. Legajo 12.323, año 1546, fol. 3170.

55 A.C.S. Sección I. Secretaría. Autos Capitulares de Cabildo Pleno. Libro 30. 10 de julio de 1571.

56 A.P.N.S. Legajo 12.403, año 1571, fol. 926.
} 
la dignidad arzobispal sobre el almojarifazgo de la ciudad de Sevilla por privilegio de Su Majestad, tanto de tiempos del arzobispo Valdés como de Gaspar de Zúñiga. ${ }^{57}$ También le vemos mandando al pregonero que diese de viva voz en almoneda pública unas casas que tenía Gaspar de Zúñiga en Lebrija (Sevilla), ${ }^{58}$ y pagando distintas pensiones sobre las rentas de la mesa arzobispal que tenían distintos señores, tanto seglares como eclesiásticos..$^{59}$

A la llegada del nuevo arzobispo don Cristóbal de Rojas (1571), Valdés siguió haciendo gestiones como receptor de los expolios pasados, y recibió del prelado 3.103.759 maravedíes que había cobrado el mayordomo de la mesa, Pedro de la Rosa, pertenecientes a la cámara apostólica. ${ }^{60}$ En 1573 se reunieron el subcolector de la cámara apostólica, el arcediano de Écija don Gerónimo Manrique, el receptor de la cámara apostólica, Simón de Valdés, y el mayordomo de la mesa de don Cristóbal de Rojas, Pedro de la Rosa, para ver la parte de los frutos y rentas de la sede vacante de don Gaspar de Zúñiga que estaban pendientes. Parte de estas rentas correspondían a los 47.000 maravedíes de juro que tenía la dignidad arzobispal de renta anual sobre el almojarifazgo de Sevilla por privilegio real. Estos los recibió Simón de Valdés del administrador del almojarifazgo. ${ }^{61}$ Para los pleitos relacionados con los expolios Simón de Valdés se sustituyó en Andrés de Hervás, Francisco de Aguilera y Pedro de Palomares, procuradores de causas en la chancillería real de Granada. ${ }^{62}$

En la sede vacante de don Cristóbal de Rojas, el 1 de abril de 1581, se reprodujo el enfrentamiento por la provisión de los oficios entre el cabildo de canónigos sede vacante y el colector del nuncio en nombre de la cámara apostólica. Reunidos en cabildo mandaron al canónigo Fernando Pérez de Saucedo que se saliera porque era subcolector de la cámara apostólica y por tanto agente del nuncio, y se trataba de un tema sobre el que había un viejo litigio: la elección de los oficiales del arzobispado en sede vacante. ${ }^{63}$

Todo lo que afectase a las posesiones y rentas de la dignidad debía contar en sede vacante con el visto bueno del colector de Su Santidad. En este caso se trataba de hacer una obra de ensanche de la calle Abades, por el lateral del palacio arzobispal, y el cabildo y regimiento de Sevilla había pedido licencia al colector, el obispo de Forlí Juan Francisco Canobio, y en su nombre al subcolector, residente en Sevilla. Parece que la calle era muy angosta y una de las más «pasajeras» de la ciudad, y para el «aprovechamiento» de la república había que derribar una pared de palacio. ${ }^{64}$

El subcolector apostólico, como representante de la cámara apostólica romana, se hizo cargo de las rentas de la mesa arzobispal para su cobro, gestión y reparto. Esto incluía el cobro de los arrendamientos de distintas propiedades de la dignidad arzobispal. Por ejemplo, Gonzalo Pérez, zapatero,

57 A.P.N.S. Legajo 12.404, año 1571, fol. 199; Legajo 12.404, año 1571, fol. 200.

58 A.P.N.S. Legajo 12.404, año 1571, fol. 399

59 A.P.N.S. Legajo 12.409, año 1572, fol. 294.

60 A.P.N.S. Legajo 12.413, año 1573, fol. 843.

61 A.P.N.S. Legajo 12.413, año 1573, fol. 868.

62 A.P.N.S. Legajo 12.418, año 1573, fol. 291.

63 A.C.S. Sección Secretaría. Autos Capitulares de sede vacante. Libro 297 (2). Sede vacante de don Cristóbal de Rojas y Sandoval, 15801581, 1 de abril de 1581.

64 A.P.N.S. Legajo 12.464, año 1581, fol. 76. pagó a la cámara apostólica, y al subcolector Hernán Pérez de Saucedo en su nombre, el arrendamiento de la tienda no 90 de las gradas, que estaban a las espaldas de las casas arzobispales, por 13.000 maravedíes al año. ${ }^{65}$

Como parte de estas rentas, el subcolector pretendía también el nombramiento de todos los oficiales del arzobispado, pues así recibiría los importes de los arrendamientos. Sin embargo, como vimos, el cabildo siempre se opuso a esta pretensión y de aquí derivó un pleito interminable. En esta ocasión dieron poder a los tres jueces del consistorio arzobispal, provisor, juez de la Iglesia y juez de testamentos para que nombrasen notarios, fiscales y demás ministros de sus audiencias, dándoles los oficios libres, sin arrendamiento ni pago alguno de dinero. De nuevo se planteaba el problema de la elección de los notarios y demás oficiales, pues el subcolector apostólico, el canónigo Hernán Pérez de Saucedo, nombró otros notarios a quienes les arrendó el oficio por una cantidad concertada. Los canónigos cometieron al provisor, doctor Negrón, y al alcaide de las casas arzobispales, doctor Hojeda, para que tratasen el asunto con el colector de la cámara apostólica e impidiesen que sus colectores arrendasen los oficios, y si fuese necesario que hicieran las diligencias que conviniesen en Sevilla y fuera de Sevilla.

Ante la falta de acuerdo, el deán contradijo la decisión del colector y el 28 de septiembre de 1581 el subcolector procedió con mandamientos y censuras ante el notario Juan de Arévalo, para que en el plazo de 24 horas revocasen el nombramiento de los notarios de los tribunales, y de lo contrario los declaraba excomulgados. ${ }^{66}$ El lunes 7 de noviembre el colector envió desde Madrid una copia del breve y motu propio de Su Santidad por el cual concedía a los colectores la jurisdicción y los nombramientos de contadores de la mesa, alcaide del palacio arzobispal, notarios de los juzgados y ministros para la administración y cobro de los frutos del arzobispado, y mandaba a los oficiales nombrados por el provisor, juez de la Iglesia y juez de testamentos que no usasen sus oficios y aceptasen los que nombrase el subcolector.

Los canónigos obedecieron el breve y mandaron a los oficiales nombrados por ellos que los obedecieran, pero protestaron y alegaron sus derechos, ordenando a don Juan Bautista Montoya, arcediano de Niebla, al canónigo doctor Luciano de Negrón, su provisor, y al doctor Hojeda, que hiciesen diligencias, tanto en Sevilla como en Madrid. Estos escribieron a la corte, al presidente de Castilla, informando cómo se había hecho la elección de los oficiales conforme a derecho, dando poder a los jueces para que los nombrasen, y los colectores de la cámara apostólica pretendían arrendarles los oficios.

En vista de la importancia del negocio, decidieron enviar a un canónigo como agente a Madrid y nombraron al doctor Luciano de Negrón para que se ocupara de varios negocios de cierta importancia pendientes en la corte, ante el nuncio, como la pretensión de Écija de hacerse obispado, la cuestión de los nombramientos de los notarios, alcaides de las casas arzobispales y otros oficios, así como otros negocios de preeminencias en sede vacante, y acordaron

\footnotetext{
65 A.P.N.S. Legajo 12.468, año 1581, fol. 255.

66 A.M.S. Sección XI. Libro 9, doc. no 13. Memorial de Negrón.
} 
«atentos que son negocios de mucha importancia qualidad y preeminencia vaya un señor beneficiado». ${ }^{67}$

En Madrid, el deán y cabildo encontraron el apoyo del fiscal del Consejo Real, que se querelló contra el subcolector por ponerles notarios y oficiales y que dio una provisión para que no procediese a nombrarlos. En una carta, Negrón explicaba cómo el deán y cabildo en sede vacante habían nombrado, como de costumbre, al provisor, al juez de la Iglesia y al juez de suplicaciones y éstos a su vez habían nombrado sus notarios, fiscales y otros ministros de sus audiencias, sin pagar nada y sin arrendamientos. ${ }^{68} \mathrm{Sin}$ embargo, el subcolector apostólico nombró a otras personas arrendándoles los oficios, y ante la oposición del deán procedió con censuras hasta excomulgarlo. En respuesta a la provisión del fiscal del Consejo, el colector apostólico de Su Santidad envió el breve por el que se concedía a los colectores que tuviesen jurisdicción, notarios, ministros y oficiales, para la administración y cobranza de las rentas y frutos del arzobispado en sede vacante.

Uno de los argumentos que esgrimía el cabildo, y que hizo suyo el fiscal, era que cuando el breve daba competencias al subcolector para nombrar oficiales solo se entendía para la administración y cobranza de la hacienda perteneciente a la sede vacante, y no para los oficiales del gobierno arzobispal. Además, el Concilio de Trento, los concilios provinciales de Toledo y Santiago y las leyes del reino, prohibían que se arrendasen los oficios de notario porque eran ocasión para que llevasen más derechos a los litigantes. Y en cumplimiento de esto, el arzobispo don Cristóbal de Rojas había dejado de arrendar estos oficios cinco años antes de su fallecimiento para evitar el «notable daño para los que litigan por que los oficiales por desquitar lo que pagan de sus arrendamientos no se contentan con los derechos de los aranceles reales y ordinarios y llevan todos los derechos que quieren». ${ }^{69}$ Así pues, fue don Cristóbal de Rojas y Sandoval en 1575 el que cesó los arrendamientos de los oficios arzobispales.

La Corona siguió presionando y haciendo gestiones ante el Papado, y este mismo año se cursaron unas instrucciones al embajador en Roma para que se conservase la costumbre castellana de que los cabildos administrasen las rentas en sede vacante sin interferencias del nuncio pontificio y colector apostólico. ${ }^{70}$ Los intentos de control por parte de la Corona de las rentas en sede vacante de los obispados y arzobispados continuaron, en el marco de una difícil convivencia entre la jurisdicción eclesiástica y la real, y en el contexto de las relaciones entre el absolutismo y la contrarreforma. ${ }^{71}$ En 1598 encontramos algunas evidencias de esta lucha por las rentas y de la indefinición jurídica en la que al parecer se desenvolvía, pues tras la muerte de un obispo:

67 A.C.S. Sección Secretaría. Autos Capitulares de sede vacante. Libro 297 (2). Sede vacante de don Cristóbal de Rojas y Sandoval, 1580-1581.

68 A.M.S. Sección XI. Archivo de El Conde del Águila, doc. no 15: Cartas Autógrafas y documentos importantes del Cabildo eclesiástico sacados de su Archivo. Un documento de 1580 de pleitos ante Negrón, p. 309

69 A.M.S. Sección XI. Libro 9. doc. 13. Memorial de Negrón.

70 García Oro y Portela Silva 1999.

71 Fernández Terricabras 1998; Olaechea 1963: 13; Domínguez Ortiz 1988: 94.
... cada qual que puede se apodera de los bienes, o azienda dellos y la cámara apostolica aze sus diligencias parar apoderarse dellos por diversas vías y nunca se a observado forma sierta y con tales confusiones por ser siempre dudoso el titulo de cada parte an sucedido en todos varios conciertos tales que quedan las haciendas en poder de... ${ }^{72}$

Además, los consejeros reales se hacían eco de que algunos, con títulos falsos y con engaños, «en gran daño de sus almas y gran deservicio de Dios», con la excusa de que eran pobres, se quedaban tan contentos con las haciendas "ganadas con poco trabajo»:

... y se van en lo profundo del infierno sino las restituyeran... y será a peor pensando todos ser licito aprovecharse de tales haciendas con crescer continuamente nuestros pecados esta maldita ambicion y ambre de allegar azienda... por lo que se ganaría gran merito y se haría gran servicio a dios si ello se remediase...

Así que pedían que la cámara apostólica tuviese título para cobrar los expolios, pues había que estar vigilantes para que no se dilapidasen las rentas del reino. De esta manera, "así como el padre debía hacer exhortaciones a su hijo", era honesto que el rey interviniese para saber qué se hacía con esa hacienda, y procurase que se convirtiese en alguna santa obra en beneficio universal. Pues los ministros calculaban que un año con otro estas rentas valían unos 25.000 ducados, y, en el contexto de la lucha contra los infieles, eran muy necesarias.

Como la cristiandad esta hoy arto vexada por los enemigo de la fe católica que se han apoderado de la mar por la qual destruyen la navegación y sea necesario por la misma mar destruirlos... para el cual esfuerzo cualquier cosa que se le aplique seria tan bien empleada como la que se aplica para hacer monasterios iglesias y obras pias... por tanto que se aplique a esto... su santidad lo haría si lo sabe negociar en servicio de dios al qual nos aiudara contra todo destorbo por su bondad y misericordia... por tanto suplico a $v$ md que tome la bandera del negocio...

En otro documento, enviado por los subcolectores generales de la cámara apostólica al rey a cuenta de los expolios, se hacía saber que en el pontificado de Paulo IV los ministros reales habían tomado algunas cantidades de dinero de expolios y frutos de sedes vacantes que pertenecían a la cámara apostólica, y pedían que se averiguase la cuenta y que se concertara sobre ello. Y puesto que los deudos de los prelados difuntos seguían usurpando los expolios, que eran bienes eclesiásticos, y los criados los robaban y no dejaban a los colectores apostólicos ejercer su jurisdicción, que el rey pusiese remedio y dejase libertad a los colectores y que los ministros de la jurisdicción real les ayudasen cuando fuesen requeridos. A cambio, teniendo en cuenta los gastos que el rey hacía contra los infieles y herejes en defensa de la religión cristiana, ofrecían una parte de los expolios para su real cámara, según concierto. A tal fin, el Santo Padre dio comisión al colector general o a quien él nombrase para que concertase con el rey estos negocios. ${ }^{73}$

72 (A)rchivo (G)eneral de (S)imancas. $(P) a(T)$ ronato $(R)$ eal, Legajo 20, doc. 56, p. 329, año 1598, El Escorial.

73 A.G.S. PTR, legajo 20, doc. 57 - 331V. Cartas de los Subcolectores generales de la Cámara Apostólica sobre los expolios. 
Con respecto a Indias, la autoridad real sobre las rentas en sede vacante episcopal se enunció por primera vez en 1543, en respuesta a la constitución de Paulo III Romani Pontificis providentia de 3 de enero de 1542, que obligaba a entregar las rentas de las vacantes a la cámara apostólica. Pero en Indias el patronato real no toleraba la presencia de colectores apostólicos. Los caudales de los expolios y vacantes estuvieron bajo el control de ecónomos reales, siguiendo un régimen similar al que habían tenido las Iglesias de la península hasta la reserva de las sedes vacantes por la Santa Sede en 1542. Finalmente, la decisión real de 1543 se convirtió en 1563 en ordenanza para todas las audiencias de América. ${ }^{74}$ En 1617 se suscitó un debate en torno a las abultadas rentas de la vacante de Charcas, pues una parte se cedía al prelado sucesor, y se planteó si era lícito que el rey aplicase estas rentas para otros fines. El fiscal del Consejo de Indias defendió la soberanía real pero otros consejeros defendían el uso prescrito en los cánones. Finalmente el Consejo determinó que su majestad podía valerse de todos los frutos en sede vacante para usos profanos pues eran bienes de la Corona. Felipe III ordenó en 1621 que una parte de las rentas fuese para el nuevo prelado, otra para la fábrica de la iglesia y otra para su majestad para limosnas y obras piadosas.

\section{LAS RENTAS EN SEDE VACANTE A PRINCIPIOS DEL SIGLO XVII}

En la sede vacante de don Rodrigo de Castro (1600-1601) ya estaba vigente la concordia que había firmado en $1597 \mathrm{Su}$ Santidad con todas las Iglesias de España, «y particularmente con la Iglesia de Sevilla» -y que fue confirmada en 1599 por Clemente VIII-, sobre la provisión de los oficios del arzobispado en sede vacante, con excepción de las notarías, que se arrendaban. ${ }^{75}$ Sin embargo, como veremos, los conflictos continuaron, pues el texto se interpretaba de distinta manera según los intereses de cada parte. Esta vez el subcolector, que era el chantre y canónigo Antonio Pimentel, armado con su breve, había comenzado a proveer todos los oficios y para tratar el asunto se presentó en el cabildo e hizo una relación de la concordia, que conocía muy bien pues había ido como diputado del cabildo a la congregación que la firmó. ${ }^{76}$

Pero, a pesar de la concordia y de los requerimientos del subcolector, los canónigos siguieron nombrando a los alguaciles eclesiásticos, aunque con la contradicción y protesta de aquel. ${ }^{77}$ Así, tras la petición de un vecino de Valencina del Alcor, Alonso Delgado Arias, el cabildo le hizo la merced de la vara de alguacil eclesiástico de la villa, que había vacado por muerte de Cristóbal de Mesa. ${ }^{78}$ Para tratar el asunto mandaron salir del cabildo al subcolector y ordenaron

\section{Tedesco 2015: 147.}

75 Seguimos los autos capitulares de la sede vacante de don Rodrigo de Castro que se encuentran en: A.C.S. Sección I. Secretaría. Autos Capitulares de sede vacante. Libro 287 (3). Sede vacante de don Rodrigo de Castro, 1600-1601, sábado 23 de septiembre 1600.

76 Ibídem, sábado 18-11-1600.

77 A.C.S. Sección Secretaría. Autos Capitulares de sede vacante. Libro 287 (3). Sede vacante de don Rodrigo de Castro, 1600-1601.

78 A.C.S. Sección Secretaría. Autos Capitulares de sede vacante. Libro 287 (3). Sede vacante de don Rodrigo de Castro, 1600-1601, sábado 13 de enero de 1601. traer las escrituras de las sedes vacantes anteriores, de don Cristóbal de Rojas y de don Gaspar de Zúñiga, para ver lo que se había hecho. Los canónigos acusaban al subcolector de exceder el breve queriendo proveer todos los oficios, así que decidieron que los canónigos Juan Hurtado y don Luis Manuel se juntasen con los letrados de la Iglesia para ver las gestiones que había que hacer en Roma sobre el asunto del nombramiento de oficios en sede vacante, y en concreto sobre el nombramiento de los alguaciles eclesiásticos, y que primero se pidiese por vía de gracia, justificándolo, y si fuese necesario que se «pida justicia».

En otro documento vemos al subcolector arrendando a un vecino de San Marcos, Luis de Santillán, los olivares anejos a la hacienda de la villa de Umbrete por la cantidad de 1320 ducados, tras la correspondiente subasta y remate. ${ }^{79}$ Con la condición de que los molinos de la dignidad fuesen entregados molientes y corrientes, para que pudiesen moler la aceituna. A cambio, el arrendatario se comprometía a pagar además 12 arrobas de aceite al mayordomo de la mesa. También se recogía en el contrato que no podía cortar ni arrancar ninguna rama de encina ni chaparro, ni maltratar los olivares, ni «enapellarlos» para coger las aceitunas, sino solo «remesellos».

La mesa, gestionada ahora por el subcolector, recibiría el cuarto de la aceituna que pagaban los vecinos de Umbrete que molían en los molinos, y esto no entraba en el arrendamiento. En la escritura se recogía además que la mesa corría con los gastos de los derechos de la contaduría que se solía pagar por los remates, a razón de 15 el millar, más los derechos del notario mayor de la mesa. Otro contrato similar se firmó para arrendar el fruto pendiente de la bellota y aceitunas del heredamiento de Lopas por 365 ducados. Aquí se incluía además dejar la "yerba» para el ganado del arzobispo desde el día de carnestolendas, y entregar a la mesa ocho fanegas de bellota limpia y buena, sin pudrir, a la mesa arzobispal. En otro documento el subcolector aparece arrendando unas «atahonas» de la mesa arzobispal que estaban dentro de las casas arzobispales por 60 reales mensuales. ${ }^{80}$

Por otra parte, los canónigos siguieron gestionando los asuntos de la sede vacante, y dieron orden de que ningún oficial cobrase dinero de capellanías ni de misas ni de ninguna otra cosa, y que el dinero que se cobrase en la sede vacante se pusiese en el arca de tres llaves, de tal modo que una llave la tuviese Antonio Pimentel, otra el mayordomo mayor de la fábrica, Andrés de Saucedo, y otra el canónigo Jerónimo Gudiel de Espina, y que los mayordomos de las fábricas entregasen el dinero en el que fueron alcanzados en las visitas y lo depositaran en el arca de tres llaves. ${ }^{81}$

El 2 de enero de 1609, ante la inminencia de la muerte del arzobispo don Fernando Niño de Guevara, el cabildo ya se estaba preparando para afrontar el eterno problema de la disputa con el colector por el nombramiento de los oficiales en sede vacante. Así que decidieron que se escribiera al cardenal de Toledo, al duque de Lerma y al nuncio, para exponer las razones que les asistían en este contencioso. Y al canónigo Benito de Vega, que estaba en Madrid, le

\footnotetext{
79 A.P.N.S. Legajo 12.604, año 1600, fol. 208-211.

80 A.P.N.S. Legajo 12.606, año 1601, fol. 520.

81 Ibídem, sábado 14 de octubre de 1600.
} 
ordenaron que siguiese las instrucciones en la defensa del derecho de la Iglesia de Sevilla en cuanto a proveer los notarios, procuradores y demás oficiales, e hiciese las diligencias oportunas con la nunciatura apostólica de acuerdo con la concordia a la que se había llegado en $1597 .{ }^{82}$ Pero a pesar de la concordia, siguieron repitiéndose los mismos conflictos. De nuevo mandaron salir del cabildo al subcolector, que en este caso era el canónigo don Manuel Sarmiento, y éste apeló la decisión. El deán respondió que en las sedes vacantes pasadas los subcolectores se habían salido del cabildo en la elección de los oficios y nombramiento de notarios. Después mandaron que se proveyesen los oficios, excepto los que se habían arrendado otras veces.

En la sede vacante de 1624 de nuevo mandaron los canónigos salir al subcolector del cabildo para proveer los oficios que faltaban de la sede vacante y éste protestó e hizo requerimientos. ${ }^{83} \mathrm{El}$ cabildo proveyó los oficios de notarios y receptores de las audiencias del provisor, juez de la Iglesia y juez de testamentos, y aumentó las plazas que había en el tribunal del provisor nombrando por procuradores a Francisco de Soto, a Alonso Cortés y a Francisco Osorio, con lo cual ascendía el número a nueve procuradores. El subcolector apostólico, don Félix de Guzmán, arcediano de Sevilla, hizo un requerimiento y apelación de estos nombramientos y el cabildo de nuevo mandó traer la concordia con los colectores para proveer los oficios. $Y$ «haviendo oído como se excedía el Subcolector de lo acordado en ella» cometieron a los señores don Manuel Sarmiento, magistral, al canónigo doctoral don Francisco Melgar, a don Diego Arias de Mendoza y al doctor Lucas de Soria, para que hicieran averiguación de los oficios que se arrendaban y a qué precios, para componerlo con el nuncio. Y en virtud de la concordia nombraron vicarios de los lugares del arzobispado, como habían hecho en otras sedes vacantes.

La disputa continuó durante el resto del siglo XVII. En 1632 la Junta Grande dictaminó sobre este tema y envió a Roma a Chumacero y Pimentel para hacer gestiones sin mucho éxito. ${ }^{84}$ Aunque las tesis regalistas habían sido ya compiladas por tratadistas como Palacios Rubio, Juan Roa de Ávila, Azpilcueta y Covarrubias no fue hasta la primera mitad del siglo XVII que se sistematizó la doctrina. Según Domínguez Ortiz, los verdaderos teóricos en esta materia fueron Jerónimo Ceballos, Pedro González de Salcedo y Francisco Salgado de Somoza, cuyas obras fueron incluidas en el Índice romano de libros prohibidos. ${ }^{85}$

En el caso de Indias, en 1635 de nuevo hubo discrepancia sobre si el rey podía disponer "con segura conciencia» de la totalidad del producto, y de nuevo hubo dictámenes contrapuestos. El fiscal del Consejo señaló que el rey era el señor legítimo de estos bienes, pero algunos consejeros opinaron que aun faltando el obispo subsistían los derechos de la Iglesia. De nuevo triunfó la opinión piadosa y Felipe

82 A.C.S. Sección Secretaría. Autos Capitulares, de Cabildo Ordinario, Libro 243, Sede vacante de don Fernando Niño de Guevara, 8 de enero de1609.

83 Seguimos en este caso los autos capitulares de la sede vacante de don Pedro de Castro que se hayan contenidos en: A.C.S. Sección Secretaría. Autos Capitulares de sede vacante. Libro 299 (4). Sede vacante de don Pedro de Castro y Quiñones. (20-12-1623).

84 Aldea Vaquero 1961, 1982; García Martín 1958; Domínguez Ortiz 1982: 80-83

85 Domínguez Ortiz 1982: 101-102.
IV mandó que no se innovase, manteniendo el reparto, sancionándose la doctrina y quedando incorporada a la recopilación de Indias en la ley 41 , tít. VII, libro 10, 8 . En 1688 se formó una junta de teólogos y ministros encargados de estudiar la cuestión de las vacantes, pero el debate se paralizó por la oposición de los miembros del Consejo de Indias. El principal escollo parecía ser la espiritualidad que los juristas otorgaban a los diezmos. ${ }^{86}$

Con la llegada de la dinastía borbónica se produjo una intensificación de la ofensiva regalista. El 22 de abril de 1709, Felipe $\mathrm{V}$ ordenó al Consejo que mandase a los corregidores y justicias de los lugares que inventariasen los expolios de su distrito. Y que las rentas que hasta entonces había recibido la cámara apostólica se pusiesen en custodia de una persona eclesiástica y una secular que elegiría el monarca en cada diócesis. ${ }^{87}$ Además se prohibió toda comunicación con Roma, incluidas las transferencias de dinero, y con el "pase regio» se trató de evitar la entrada de documentos y bulas que pudiesen perjudicar al estado. ${ }^{88}$

Finalmente, las aspiraciones de la Corona al control de las rentas eclesiásticas bajo la forma del patronato real, aunque según algunos autores eran ya un hecho en el reinado de los Austrias, ${ }^{89}$ fueron impulsadas por los Borbones hasta alcanzar el concordato de 1753 , con el que se conseguía disminuir la salida de numerario en dirección a Roma. ${ }^{90}$ En virtud del concordato, el rey nombraría ecónomos y colectores bajo su protección que administrasen y distribuyesen las rentas, ${ }^{91} \mathrm{y}$ en compensación depositaría en Roma 233.333 escudos y se obligaría a pagar una renta anual de 5.000 con destino a la manutención y subsistencia de los nuncios apostólicos. ${ }^{92}$ A partir de aquí la Colecturía General de Espolios y Vacantes recaudó y administró durante casi un siglo las rentas de los obispados cuando sus sedes se encontraban vacantes, dando lugar a una importante documentación contable. ${ }^{93} \mathrm{EI}$ conflicto entre regalismo y antirregalismo continuará el resto del siglo, y Campomanes y Olavide serán los personajes más denostados por el partido «españolista» hasta el punto de acusarlos de herejes. ${ }^{94}$

\section{CONCLUSIONES}

Así pues, en el caso del arzobispado de Sevilla y en el período de tiempo estudiado (1482-1624), parece que la disputa por el expolio y las rentas en sede vacante se

\footnotetext{
86 Tedesco 2015: 148.
}

87 García Villoslada, R. 1982. Historia de la Iglesia Española. Tomo IV, Apéndice I, Ruptura entre España y Roma (1709). Decreto del Rey Felipe V, en 22 de abril de 1709, Sobre los asuntos eclesiásticos que solían expedirse por el Papa en Roma: 795-796. Madrid: Editorial Católica. Fuente: J. A. Llorente, Colección diplomática: 25-27.

88 Egido 1982a: 163.

89 Domínguez Ortiz 1988: 94; Egido 1982b.

90 Domínguez Ortiz 1988: 107.

91 A.M.S. Sección XI. Archivo del Conde de El Águila. Tomo $2^{\circ} / 6^{\circ}$. Arzobispos de Sevilla, tomo 2‥

92 Golmayo 1896, Tomo II: 300 y ss.; García Villoslada, R. 1982. Íbidem. Tomo IV, Apéndice III. Concordato de 1753 entre Su Majestad Católica Fernando VI y el Papa Benedicto XIV; Egido 1982b: 163; García Villoslada, R. 1982. Íbidem. El Concordato de 1753 y el cambio del sistema. 2. Contenido del Concordato: 185.

93 Calvo Cruz 2005.

94 Egido 1982c: 245. 
mantenía básicamente entre el cabildo, como administrador de la jurisdicción ordinaria del prelado tras su muerte, y el colector en nombre de la cámara apostólica. Además, en algunos momentos aparece también el heredero del prelado muerto que reclama su parte de la herencia.

En las dos primeras sedes vacantes estudiadas, la de don Pedro González de Mendoza (1482) y la de don Diego Hurtado de Mendoza (1503), la intervención de los reyes haciendo valer su derecho de "guardanía» fue enérgica y decidida. En el primer caso, incluso nombraron su propio colector de las rentas y dieron orden a los corregidores y oficiales de los cabildos seglares para que le obedecieran y facilitasen el cobro de las rentas. A veces los reyes también reclamaron parte de las rentas a los canónigos, como en el caso de las tenencias de las fortalezas, pero éstos alegaban que el cobro correspondía al subcolector, puesto que estaban en sede vacante. Se trataba de sacar algún beneficio apoderándose de parte o de todas las rentas de la segunda sede episcopal española por su importancia económica.

Sin embargo, al menos en la documentación que hemos podido consultar, los canónigos acudieron en apelación ante el rey y la reina y ante su Consejo en 1503 y a partir de aquí la intervención real se limitó a actuar en favor de las pretensiones del cabildo. En forma de apoyo del presidente de Castilla y de querella del fiscal del Consejo Real contra el subcolector en 1581 o de intervención del duque de Lerma en 1609.

El mecanismo se repite básicamente a lo largo del período. En 1485 vemos un apoderado representando los intereses del colector de la cámara apostólica, pero a partir de 1503 el colector nombra un subcolector, que solía ser un canónigo residente en Sevilla, que se presenta en cabildo armado con un breve para la defensa de los intereses de Roma. De esta manera se aseguraba la presencia de éste en el lugar de la reclamación, y el conocimiento del entramado de intereses en el que se iba a desenvolver. Sin embargo esto suponía un conflicto de lealtades, que se solía sustanciar en su expulsión del cabildo cuando se reunía en capítulo para tratar temas de la sede vacante.

El cabildo solía actuar bajo la premisa del «obedézcase pero no se cumpla», pues acataba formalmente el breve pero paralelamente tomaba decisiones para asegurar la jurisdicción ordinaria del prelado. Para controlar el proceso de cobro y reparto de las rentas nombraba sus propios oficiales (receptores, contadores y tesorero) a los que se les ordenaba que no acudiesen con las rentas al subcolector. $Y$ daba órdenes a los oficiales nombrados por el subcolector para que no se entrometiesen en el cobro y reparto de las rentas. Una parte de los bienes, una vez descontado el pago de los salarios de los oficiales sede vacante, correspondía a la cámara apostólica, y otra parte, la de la mesa, una vez descontado el pago de las reparaciones que fuesen necesarias en las casas y fortalezas, correspondía a los herederos del arzobispo.

El conflicto por el nombramiento de los oficiales se complicaba porque, a su vez, el subcolector pretendía nombrar no sólo los de la mesa, implicados en el cobro y gestión de las rentas, sino al resto de oficiales mayores y menores del consistorio y corte arzobispal, para cobrar los arrendamientos de algunos de estos oficios. Sin embargo, el cabildo catedral sevillano alegaba que tenía mayores prerrogativas que el resto de las iglesias de España en sede vacante, pues además del gobierno y administración del arzobispado, había nombrado desde tiempo inmemorial a los oficiales mayores y menores del gobierno arzobispal.

En el ínterin era frecuente que los canónigos hiciesen gestiones en Madrid, ante el nuncio y ante el Consejo Real. Finalmente el conflicto se resolvía con las amenazas de excomunión por parte de la Santa Sede, ante la cual cedían los canónigos alzando el secuestro y embargo de los frutos del arzobispado, aunque paralelamente protestaban, apelaban y contradecían las decisiones del colector, pues según ellos perjudicaba la preeminencia de su Iglesia. En esta lucha jugaba a favor de la cámara apostólica el poder del nuncio para fulminar censuras de excomunión que solo se podían resolver apelando a Roma.

Por tanto, a pesar de los acuerdos firmados, y muy especialmente la concordia de 1597 con la Santa Sede, a la que se alude repetidamente en los autos capitulares de sede vacante, los conflictos continuaron y, a excepción de la reclamación por los arrendamientos de los oficios, que cesaron por decisión real en 1575 , el resto de quejas y conflictos siguieron básicamente el mismo recorrido y el mismo patrón de actuación durante todo el período estudiado.

\section{BiBLIOgRAFÍA}

Aguadé Nieto, S. 1982. "Crisis de subsistencia, rentas eclesiásticas y caridad en la Castilla de la segunda mitad del siglo XV». Estudios en memoria del Profesor D. Salvador de Moxó. En la España medieval II: 21-48.

Aldea Vaquero, Q. 1961. «Iglesia y estado de España del siglo XVII (Ideario político-eclesiástico)». Miscelánea Comillas: Revista de Ciencias Humanas y Sociales 19 (36): 143-544.

Aldea Vaquero, Q. 1982. «Iglesia y Estado en la época barroca», en F. Tomás y Valiente (coord.), La España de Felipe IV: el gobierno de la monarquía, la crisis de 1640 y el fracaso de la hegemonía europea: 525-633. Madrid: Espasa-Calpe.

Azcona, T. 1982. «Reforma del episcopado y del clero. Reforma beneficial», en R. García Villoslada, Historia de la Iglesia española. Tomo IIII: 115-210. Madrid: Editorial Católica.

Azcona, T. 1984. «Derecho de Patronato y presentación a la Iglesia de Pamplona. Privilegio de Adriano VI a Carlos V en 1523». Scripta Theologica 16 (1-2): 499-542.

Barrio Gozalo, M. 1987. "La economía de las mutuas catalanas en la segunda mitad del siglo XVIII y su relación con el conjunto español. Apuntes para su estudio». Pedralbes: Revista d'Història Moderna 8 (II): 447-457.

Barrio Gozalo, M. 1990. «Aproximación a la economía de las mitras catalanas en la segunda mitad del siglo XVI», en Jornades d'Història Antoni Agustín i el seu temps (1517-1586). Tarragona.

Barrio Gozalo, M. 2004. El Real Patronato y los obispos españoles del Antiguo Régimen (1556-1834). Madrid: Centro de Estudios Políticos y Constitucionales.

Barrio Gozalo, M. 2010a. El clero en la España moderna. Córdoba: CSIC. Barrio Gozalo, M. 2010b. "Las rentas de los obispos de Cataluña en el Antiguo Régimen (1556-1837)». Manuscrits 28: 143-179.

Barrionuevo, J. 1968. Avisos 1654-1658, edición y estudio preliminar de A. Paz y Melia. Madrid: Atlas.

Calvo Cruz, M. 2005. «Rendición de cuentas de los administradores del Obispado en sede vacante en España, siglos XVIII-XIX». Revista de Contabilidad 8 (15): 169-182.

Carande, R. y Carriazo, J. M. 1968. El Tumbo de los Reyes Católicos del Consejo de Sevilla. Tomo III, 1479-1485. Sevilla: Universidad Hispalense. 
Carretero Zamora, J. M. 2013. «La Colectoría de España en el siglo XVI: los mecanismos de transferencia monetaria entre España y Roma (cambios y créditos)». Hispania LXXIII (243): 79-104. https://doi. org/10.3989/hispania.2013.003

Castillo Maldonado, P. 2012. «In hora mortis: deceso, duelo, rapiña y legado en la muerte del obispo visigótico». Hispania Sacra LXIV (129): 7-28. https://doi.org/10.3989/hs.2012.001

Díaz Martín, L.V. 1981. "El pontificado y Castilla en el marco de las relaciones internacionales a mediados del siglo XIV». Archivos leoneses XXXV (35): 351-386.

Domínguez Ortiz, A. 1974. "Las rentas episcopales de la Corona de Aragón en el siglo XVIII», en G. Tortella y J. Nadal (coords.), Agricultura, comercio colonial y crecimiento económico en la España contemporánea: actas del Primer Coloquio de Historia Económica de España: 13-43. Barcelona: Ariel.

Domínguez Ortiz, A. 1982. "La Monarquía española y el Pontificado en el siglo XVII. Crisis en las relaciones entre España y Roma», en R. García Villoslada, Historia de la Iglesia española: Tomo IV. Madrid: Editorial Católica.

Domínguez Ortiz, A. 1988. Sociedad y Estado en el siglo XVIII español. Barcelona: Ariel.

Egido, T. 1982a. «Las tensiones entre la Iglesia y el Estado en la primera mitad del siglo XVIII. La ruptura entre Felipe V y el Papa», en R. García Villoslada, Historia de la Iglesia en España: Tomo IV. Madrid: Editorial Católica.

Egido, T. 1982b. «El regalismo y las relaciones Iglesia-Estado en el siglo XVIII», en R. García Villoslada, Historia de la Iglesia en España: Tomo IV. Madrid: Editorial Católica.

Egido, T. 1982c. «La oposición antirregalista. Ofensiva antirregalista y crisis de gobierno: las campañas de 1776», en R. García Villoslada, Historia de la Iglesia en España: Tomo IV. Madrid: Editorial Católica.

Fernández Alonso, J. 1954. «Los enviados pontificios y la colectoría en España de 1466 a 1475». Anthologica Annua 2: 51-122.

Fernández Alonso, J. 1957. «Nuncios, colectores y legados pontificios en España de 1474 a 1492». Hispania Sacra 10: 33-90.

Fernández Alonso, J. 1963. Legaciones y nunciaturas en España de 1426 a 1521. Roma: Instituto Español de Historia Eclesiástica.

Fernández Conde, J. y Oliver, A. 1982a. «Centralismo administrativo y fiscalismo de Aviñón. Sus incidencias en la Iglesia española», en R. García Villoslada. Historia de la Iglesia en España. Tomo II. Madrid: Editorial Católica.

Fernández Conde, J. y Oliver, A. 1982b. «La Corte pontificia de Aviñón y la Iglesia Española», en R. García Villoslada, Historia de la Iglesia en España: Tomo II. Madrid: Editorial Católica.

Fernández de Córdova Miralles, A. 2005. Alejandro VI y los Reyes Católicos Relaciones político-eclesiásticas (1492-1503). Roma: Thesis ad Doctoratum in Theologia.

Fernández Terricabras, I. 1998. «El Episcopado hispano y el patronato real: Reflexión sobre algunas discrepancias entre Clemente VIII y Felipe II», en J. Martínez Millán (dir.), Felipe II (1527-1598): Europa y la monarquía católica. Congreso Internacional Felipe II (1598 1998), Europa dividida, la monarquía católica de Felipe II: vol. 3 , 209-224. Madrid: Universidad Autónoma.

García Martín, N. 1958. «Esfuerzos y tentativas del conde-duque de Olivares para exonerar de los espolios y vacantes a los prelados hispanos». Anthologica Annua 6: 231-281.

García Oro, J. y Portela Silva, M. J. 1999. «Felipe II y las rentas eclesiásticas de la Corona de Castilla», en El legado cultural de la iglesia mindoniense: 185-214. Ferrol, I Congreso do Patrimonio da Diócesis de Mondoñedo.

Golmayo, P. B. 1896. Instituciones del Derecho Canónico. Madrid: Librería de Gabriel Sánchez.

Goñi Gaztambide, J. 1958. «El derecho de espolio en Pamplona en el siglo XIV». Hispania Sacra 11: 157-174.
Goñi Gaztambide, J. 1959. «Incidente en torno al espolio de don Arnalt de Barbazán, obispo de Pamplona». Pregón 59.

Goñi Gaztambide, J. 1960. «Arnalt de Barbazán, obispo de Pamplona y Felipe III, rey de Navarra». Miscelánea Antonio Pérez Goyena. Estudios eclesiásticos 35 (1): 397-413.

Goñi Gaztambide, J. 1962. "Los obispos de Pamplona del siglo XIV». Príncipe de Viana XXIII (86-87): 309-400.

Goñi Gaztambide, J. 1979. Historia de los Obispos de Pamplona. Pamplona: Universidad de Navarra.

Hermann, Ch. 1988. L'Eglise d'Espagne sous le patronage royal (14761834). Madrid: Casa de Velázquez.

Mendi. J. 1964. «La primera legación del cardenal Guido de Boulogne a España (1358-1361)». Scriptorium victoriense 11 (1-2): 135-224.

Novísima Recopilación de las leyes de España: Dividida en XII libros. En que se reforma la Recopilación publicada por el Señor Don Felipe II en el año 1.567, reimpresa últimamente en el de 1.775: Y se incorporan las pragmáticas, cédulas, decretos, órdenes y resoluciones Reales, y otras providencias no recopiladas y expedidas hasta el de 1.804. Mandada formar por Carlos IV. Madrid: (s.n.), 1805-1829.

Olaechea, R. 1963. Las relaciones hispano-romanas en la segunda mitad del siglo XVIII. Zaragoza.

Ortuño Molina, J. 2002. Sínodo de diócesis de Cartagena (1475). Murcia: Universidad de Murcia.

Pérez Prendes, J. M. 1986. «Relaciones Iglesia-Estado en la formación del Estado moderno. El Real Patronato: aportación para un estudio de la cuestión", en J.-P. Genet y B. Vincent (eds.), Etat et église dans la genèse de l'État moderne: 149-255. Madrid: Casa de Velázquez.

Pujol Aguado, J. A. 1995. «El clero secular al servicio del Estado. Intento estatal de control de la Iglesia durante la Guerra de Sucesión». Revista de Historia Moderna 13-14: 73-93. https://doi.org/10.14198/rhm1995.13-14.04

Rey Castelao, O. 1987. "La protección jurídica de las rentas eclesiásticas en España: El ejemplo del voto de Santiago». Hispania Sacra 39 (80): 457-503.

Serrano y Pineda, L. 1915. «Alfonso XI y el papa Clemente VI durante el cerco de Algeciras». Cuadernos de Trabajo. Escuela Española de Arqueología e Historia en Roma 1-3: 1-35.

Tedesco, E. M. 2015. "La construcción de la exclusiva jurisdicción del rey en materia decimal durante el debate de las vacantes de las iglesias de Indias». Terceras Jornadas de Historia Económica: 146165. El Colegio de México.

Trenchs Ódena, J. 1970-1971. «Las tasas apostólicas y el gratis papal en la primera mitad del siglo XIV». Anuario de Estudios Medievales 7: 314-335.

Trenchs Ódena, J. 1978. "Aspectos de la fiscalidad pontificia en la diócesis de León (1300-1362)», en León Medieval. Doce estudios: 117-137. León: Colegio Universitario.

Villaroel González, O. 2013. «La tributación de los eclesiásticos castellanos en el siglo XV: entre el Rey y el Papa», en J. Morelló Baget (ed.), Financiar el Reino Terrenal. La contribución de la Iglesia a finales de la Edad Media (s. XIII-XVI): 311-339. Barcelona: CSIC, Institución Milá i Fontanals

Zunzunegui, J. 1953. "La Cámara apostólica y el reino de Castilla durante el pontificado de Inocencio VI, (1352-1362)». Anthologica Annua 1: 156-184.

Zunzunegui, J. 1960. «La misión del obispo de Senez al reino de Castilla (1354-1355)». Anthologica Annua 8: 11-42.

Zunzunegui, J. 1961. "Un episodio de la recolección de la décima otorgada al infanta Pedro de Castilla (1317)». Scriptorium Victoriense 8: $170-173$.

Zunzunegui, J. 1964. «La legación del cardenal Guillermo de la Jugie a Castilla y Aragón (1355-1358)». Anthologica Annua 12: 129-156. 